\section{EREM 72/3}

Journal of Environmental Research, Engineering and Management Vol. 72 / No. 3 / 2016 pp. 7-17
The Influence of Temperature Change on Crack Openings in a Reinforced Concrete Shell of Pressure Piping at Kruonis Pumped Storage Power Plant

Accepted after revision 2016/12

\title{
The Influence of Temperature
} Change on Crack Openings in a Reinforced Concrete Shell of Pressure Piping at Kruonis Pumped Storage Power Plant

\author{
Raimondas Šadzevičius, Vincas Gurskis, Rytis Skominas, Tatjana Sankauskienė
} Institute of Hydraulic Engineering, Faculty of Water and Land Management, Aleksandras Stulginskis University, Kaunas Universiteto 10, 53361 Akademija, Kaunas dist., Lithuania

Corresponding author: raimondas.sadzevicius@asu.lt

R. Šadzevičius, Institute of Hydraulic Engineering, Faculty of Water and Land Management

Aleksandras Stulginskis University, Universiteto 10, 53361 Akademija, Kaunas dist., Lithuania

Cracks are classified according to their geometry (length, width and depth), statistical parameters (mean and variance of the number of cracks per unit area), crack riskiness for structures, etc. In this paper, crack openings in a reinforced concrete shell of the pressure piping at Kruonis Pumped Storage Power Plant, which appeared due to temperature change, are analysed. Detailed analysis of cracks and deformations due to temperature changes was performed after the evaluation of the technical state of the pipeline. Specific illustrations, calculations and guidance for repair of these deteriorations were offered.

Keywords: temperature change, hydraulic structures, reinforced concrete pipes, cracks. 


\section{Introduction}

Hydraulic structures are usually built using hydraulic concrete. Its density, water resistance and durability have to meet high requirements, and the categories of the environmental conditions for its usage are presented in the norms of design and standards (EN 206:2014; STR 2.05.05:2005; STR 2.05.18:2005, etc.). Although concrete is a durable material, which handles well compressive stresses, it is not resistant to tensile stresses and, as a result, it cracks frequently.

Cracks are classified according to their geometry (length, width and depth), statistical parameters (mean and variance of the number of cracks per unit area), characteristic cracking stages when the external load of construction increases, etc. (Chen et al. 2005; Gelžbetoniniu ..., 1997, 1998; Jokūbaitis 2007). From the theoretical point of view, such classifications can be easily applied; however, they do not provide enough information when practical issues must be solved. In the evaluation of cracks of an element, the most important factor is their harmfulness to the construction. In accordance with such a view, cracks are grouped in the following manner (Gelžbetoniniu ... 1997):

1 Harmless cracks which only erode quality of surface;

Harmful cracks which considerably weaken the cross-section of construction;

3 Partly harmful cracks which worsen the usage of an element, reduce the liability and the durability of construction; however, they do not cause any direct danger, in which case, additional factors must be present for the construction to disintegrate.

Constructions where cracks belonging to the second or the third group are identified have to be repaired in accordance with building regulations (ST 120793378.05:2015; ST 120793378.01:2014; ST 120793378.02:2015). The change in the width of cracks in time must be observed by installing temporary recording or fixed mechanical strain gauges.

Previous research (Gelžbetoninių... 1997; 1998, Šadzevičius et al. 2009) has shown the reasons of cracks appearing in hydraulic structures to be mistakes of design, deviations from the requirements for the constructions' production and the design of structures, infringement of rules of constructions' production and building technology, unsuitable usage of structures, change of usage conditions and natural disasters.

Cracks can be technological (appear during the usage time of construction), regular (appear under the design load) or unexpected (appear due to accidental impacts). The appearance of cracks in concrete or reinforced concrete constructions is calculated following the condition that internal forces, stresses and deformations caused by various impacts and their combinations cannot surpass the respective limit values, which can be borne by construction at the moment of crack opening. The width of cracks is calculated using the condition according to which the width of cracks in a construction caused by various impacts and their combinations cannot surpass the limit value indicated in STR 2.05.05:2005 Table 24. These calculations depend on the requirements for the construction, its usage conditions and aggressiveness of environment. This paper concentrates mainly on normal and oblique cracks appearing due to restrained deformations and cracks appearing due to uneven heating of a cross-section (Jokūbaitis 2007; Jokūbaitis and Šiaučiuvenas 2012).

These cracks are mainly caused by temperature impacts; thus, there are temperature changes during the usage of structures. Some authors have investigated the effects of internal water pressure (Siddiqui and Fowler 2014) or earth pressure (Iskander 2013) on the coefficient of thermal expansion of concrete. This coefficient was established using the micromechanical model (Zhou et al. 2012, 2014) or measured and evaluated (Wang et al. 2013) according to the type of coarse aggregates (Naik et al. 2011). Theoretical examples of the calculation of measurement thermal stresses in massive hydraulic structures are presented by Bofang (2014). Field investigations of temperature impacts on hydraulic structures and crack openings in these structures have not been performed in Lithuania.

The aim of the research was to evaluate the influence of temperature change on crack openings in a reinforced concrete shell of the pressure piping at Kruonis Pumped Storage Power Plant (Kruonis PSPP). The object of the research was the pressure piping at Kruonis PSPP. 
The tasks to reach the aim were set as follows:

1 To evaluate defects, damages and the technical state of the pressure piping at Kruonis PSPP;

2 To evaluate deformations of the piping caused by temperature and cracks in a reinforced concrete shell of the pressure piping appearing as a consequence;

3 In accordance with research results, to offer reconstruction solutions for piping maintenance.

\section{Technical parameters of the pressure piping at Kruonis PSPP}

According to possible consequences of breakdowns and usage malfunctions, hydraulic structures can be grouped into 4 consequence classes (CC1, CC2, CC3 and CC4) described in STR 2.02.06:2004. The classes of hydraulic structures of Kruonis PPSP researched in 2014 were determined as CC2-CC4. The pressure piping analysed in this paper connects the lower pool with the upper pool via the system of energy facilities. Four pipings are built of reinforced concrete. Every set has its own pipe. The length of one pipe is $840 \mathrm{~m}$; the inside diameter is $7,500 \mathrm{~mm}$; the wall thickness is $400 \mathrm{~mm}$; the inside is covered with a $10 \mathrm{~mm}$ leaf of steel. The pipe is divided into 4 sections of $40 \mathrm{~m}$, which are each separated by a compensator of temperature deformations. The axis of pipes is a pipeline of different inclination and is adapted to the relief. The piping is built on a pile foundation relaying on reinforced concrete beams of $16-25 \mathrm{~m}$ long and $1 \mathrm{~m}$ wide via grade beams and grillage. The load capacity of each beam is $320 \mathrm{kN}$ (32 t). The piping area (field of piles) is covered with a concrete layer of $20 \mathrm{~cm}$. Water accumulation chutes and rainwater-harvesting tanks are installed every 40 meters.

The maximum speed of water in the pipe, when the generator is active, is $5.67 \mathrm{~m} / \mathrm{s}$. The maximum speed of water in the piping, while in the pumping mode, is $4.28 \mathrm{~m} / \mathrm{s}$. Limit values for pressure piping constructions are established by the designer. Limit subsidence of piping sections is $30 \mathrm{~mm}$. Limit width of subsidence cracks caused by a change in temperature is $40 \mathrm{~mm}$. Limit width of cracks caused by a change in temperature is $25 \mathrm{~mm}$. Limit tensile stresses of longitudinal reinforcement are $300 \mathrm{MPa}$.

\section{Methods of research}

During the field investigation, the following diagnostic methods for constructions were applied: visual examination including preliminary observation of constructions was performed and mostly damaged areas, type of cracks, their width and depth were determined. According to observed defects and damages, a visual onthe-spot evaluation of the technical state, photo-fixation and video recording were performed. Research studies of existing constructions are carried out using the methods listed in technical standards STR 1.03.01:2016, STR 1.12.03:2006; however, having analysed photo and video material, methods of state evaluation (Ramonas 2007; Kruonio HAE... 2007) were used to score the state of the piping according to the observed damages.

Instrumental methods were used in order to measure the width of cracks and the strength of concrete; the width of existing cracks was measured using Elcometer 143 Crack Width Ruler (range 0,10 - 2,50 mm) and a microscope Elkometer 7220 (×30 magnification) (Figure 1).

In order to process the results of research, statistical methods were used. Temperature deformations of reinforced concrete constructions and characteristic temperatures of the pressure piping were calculated using the formulas of building physics.

\section{Fig. 1}

The illustration of measurement of crack width using Elcometer 143 Crack Width Ruler and a microscope Elkometer 7220. Source: taken by authors

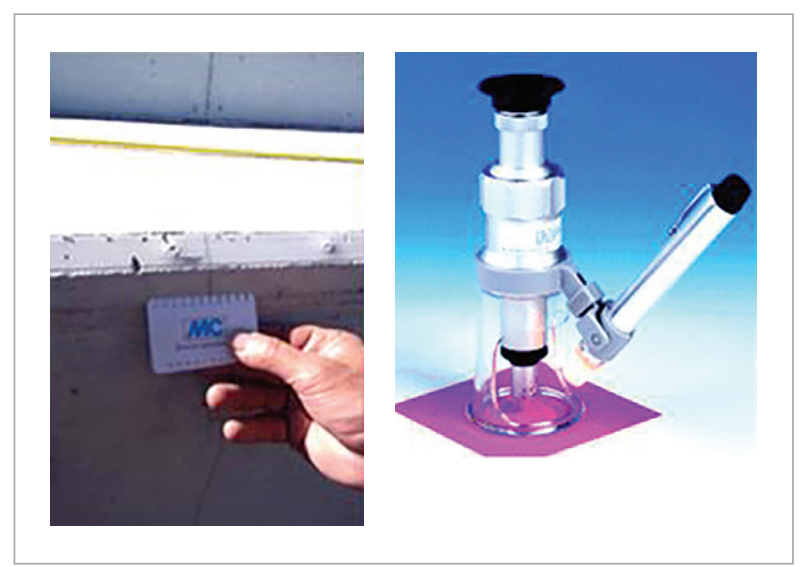




\section{Research results of the technical state of the pressure piping at Kruonis PSPP}

During the visual investigation, the main defects and damages in the pressure piping of Kruonis PSPP were determined:

1 In some compensators, concrete in the sections of neighbouring pipes was in contact or almost in contact;

2 The top layer of the piping was cracked due to the impact of temperature deformations;

3 Seeping precipitation water leached out $\mathrm{Ca}(\mathrm{OH})_{2}$ from concrete, and steel elements and supplementary details were affected by corrosion.

A more detailed description of research results is presented in the research report of the technical state of Kruonis PSPP (Kruonio HAE... 2014).

The observed damages worsen the technical and the aesthetic state of this important part at Kruonis PSPP.

It is indispensable to eliminate defects and damages in order to maintain the structure's safety and avoid considerably higher costs for overdue maintenance.

\section{Damages and deformations due to change of temperature in reinforced constructions of the pressure piping at Kruonis PSPP}

Piping cracking. The surface of the top and the sidewalls of the piping are covered with dust and are considerably darker than the bottom surface.

This layer of dust results in humidity from precipitations, which needs more time to evaporate, and in the darker surface, which heats up more because of sun radiation.

This is the cause of different temperature deformations and stresses at the top and the bottom of the piping inasmuch as outside and inside the piping.

Cracking on the surface of concrete due to differences in temperature is shown in Figure 2.
This cracking could be explained by an unsuitable treatment of concrete in the process of solidification (an over-dried surface layer of concrete increases shrinkage deformations) and also by different temperature deformations in the inside and outside surfaces of the pipes, as cracks open on the outside surface when, due to negative temperature during winter time, it becomes cold and shrinks. It was established (Figure 3) that, when there is a difference of $11^{\circ} \mathrm{C}$, shrinkage deformations, which match limit ductility of concrete, appear; and when there is a bigger difference between temperatures, longitudinal cracks open on the surface of concrete. The temperature dropdowns in the walls of the pressure piping, when the temperature on the inside of the pipe is $+4^{\circ} \mathrm{C}$ and on the outside $-20^{\circ} \mathrm{C}$, are shown in Figure 3.

\section{Fig. 2}

Cracking in the surface of concrete at the top of the pressure piping. Source: taken by authors

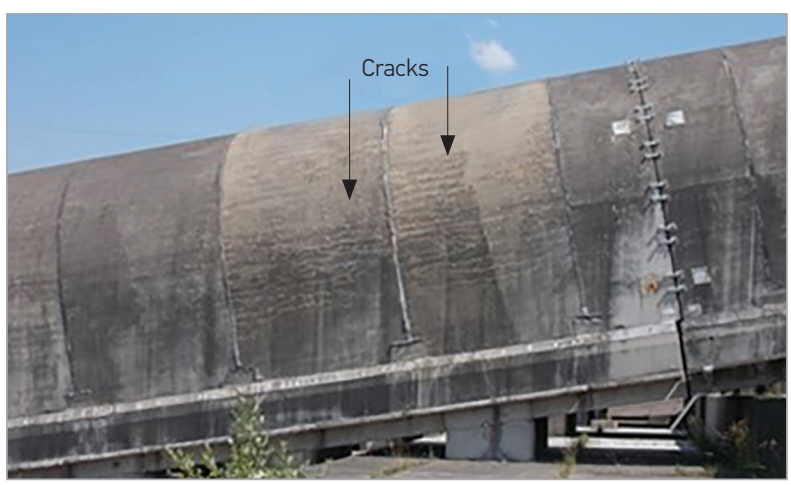

Fig. 3

Temperature changes in the surface layer of concrete at the top of the pressure piping. Source: drawn by authors

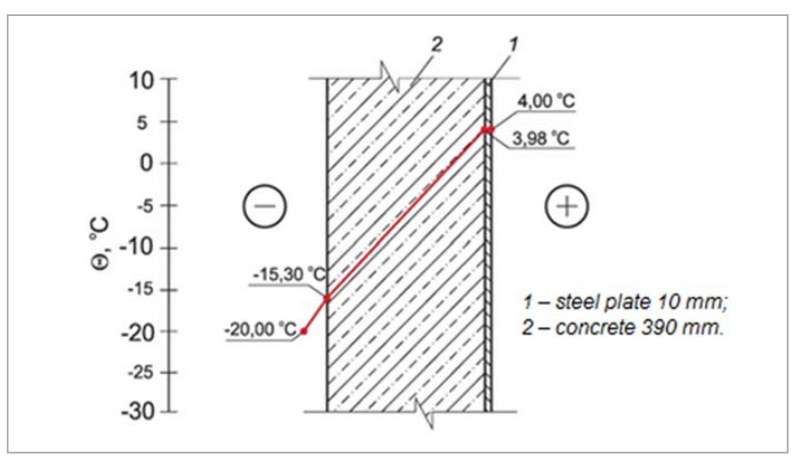


Longitudinal cracks during winter time caused by circular temperature deformations are shown in Figure 4.

Fig. 4

Distressed concrete in the bottom part of the surface in section 17 of the third pipe: seeping water leaches out calcium hydroxide. Source: taken by authors

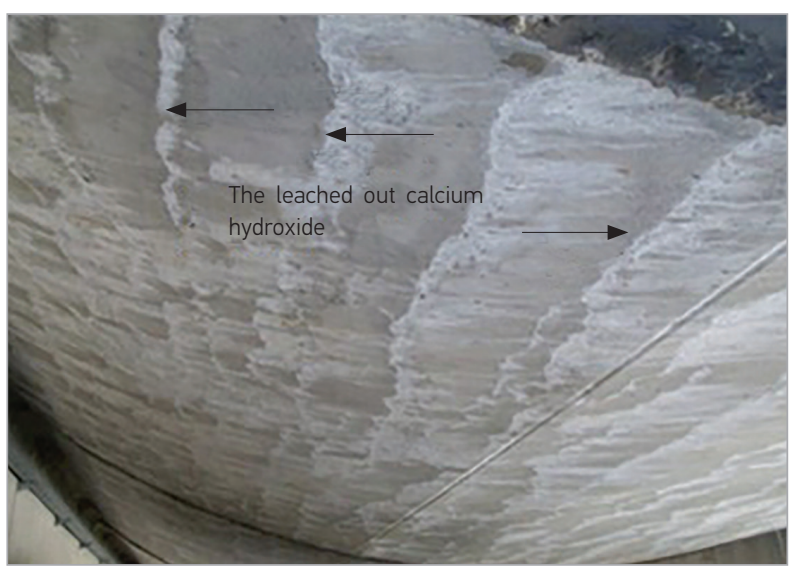

Due to temperature deformations, tensile stresses, which surpass the limits, appear in the concrete (Figure 5).
Temperature deformations were calculated from the thermal expansion coefficient (Gurskis 2008):

$$
\propto=\frac{l_{2}-l_{1}}{l_{1}\left(\Theta_{2}-\Theta_{1}\right)}=\frac{\Delta l}{l_{1} \cdot \Delta \Theta} K^{-1}
$$

where

$\Delta l$ - length change; $l_{1}$ - original length of material specimen; $\Delta \theta$ - temperature change.

Temperature deformations are equal to:

$$
\Delta l=\propto \cdot l_{1} \cdot \Delta \Theta
$$

where

The thermal expansion coefficient $\propto=1.2 \cdot 10^{-5} \mathrm{~K}^{-1}$.

Such causes of cracking in a pipe are not foreseen in the design, and the joints of longitudinal temperature deformations are not installed.

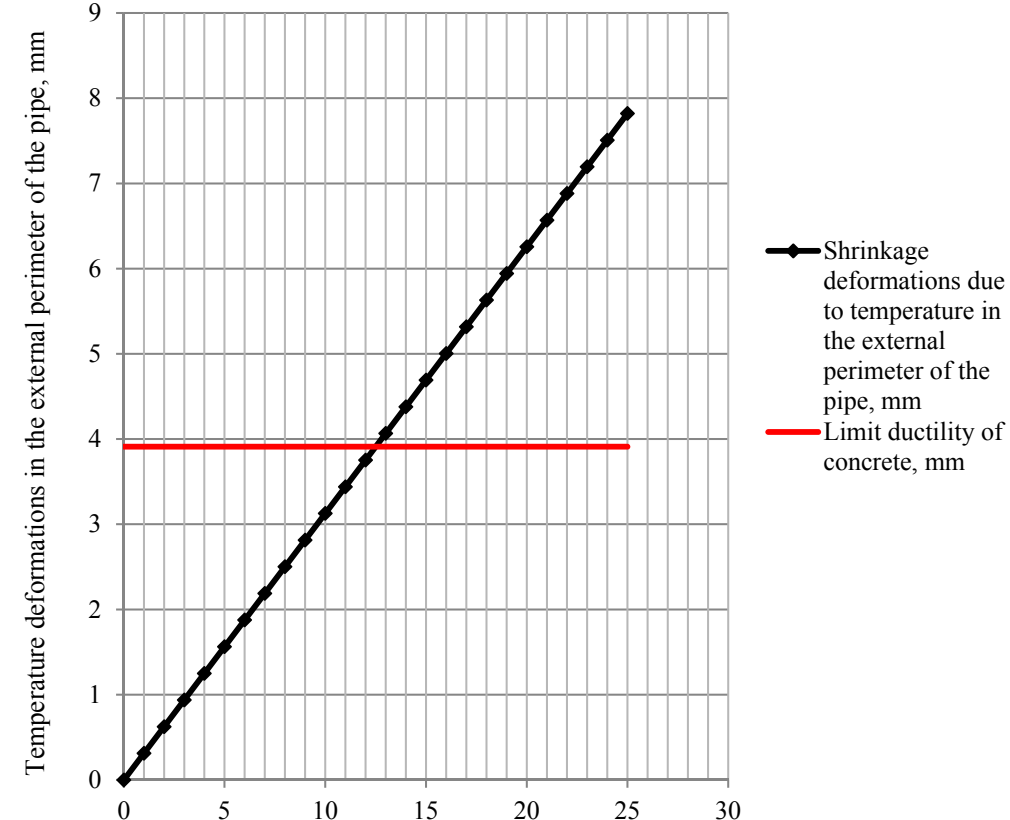

The difference between the temperature of the inside and outside surfaces of the pipe ${ }^{\circ} \mathrm{C}$
Fig. 5

Deformations caused by differences in temperature. Source: drawn by authors 
Temperature deformations in piping sections. It was established during the visual investigation that certain joints connecting the piping sections were sealed with unsuitable mortars, which were cracked and did not ensure joints tightness (Figure 6).

\section{Fig. 6}

Joints of the piping sections sealed with cement mortar, which is cracked. Source: taken by authors

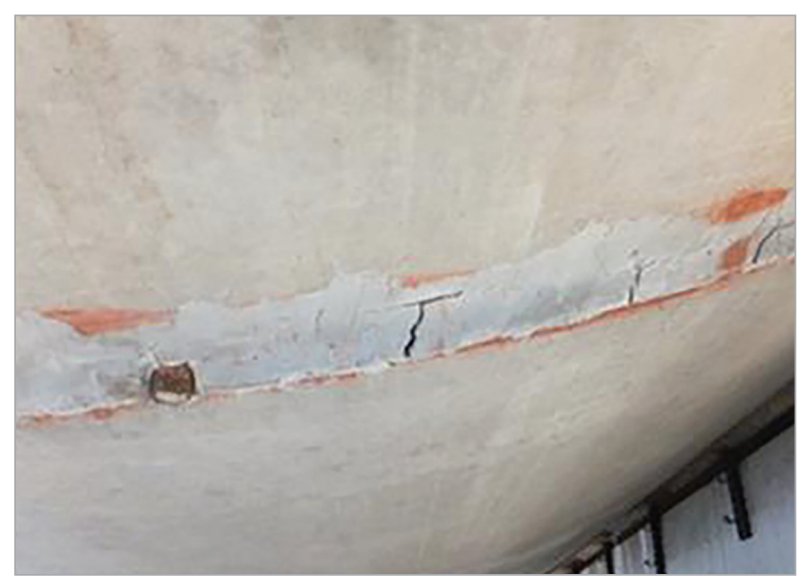

Concrete of different elements in the compensators of the pressure piping is in contact or almost in contact (Figure 7). The reason of this defect is concrete shuttering, which was inaccurately built or damaged during concrete construction works. It is indispensable to eliminate the defects by increasing the width of joints in order to match the one specified in the design. Over the last few years, maintenance works have been performed: spaces have been widened by cutting out the concrete in contact. Steel details in the compensators of the piping are damaged by corrosion.

Theoretical calculations (according to formula 1 and 2) showed that if the sun radiation created a difference of $10^{\circ} \mathrm{C}$ between the temperature at the top, which is dark and dusty, and the bottom of the piping, the top layer of $40 \mathrm{~m}$ long piping sections would become longer by $4.8 \mathrm{~mm}$ and the entire $840 \mathrm{~m}$ long piping would become longer by $100.8 \mathrm{~mm}$. Due to different temperature deformations at the top and the bottom of the piping, there is a possibility of additional stresses in the compensators. Temperature deformations along the piping section are shown in Figure 8.

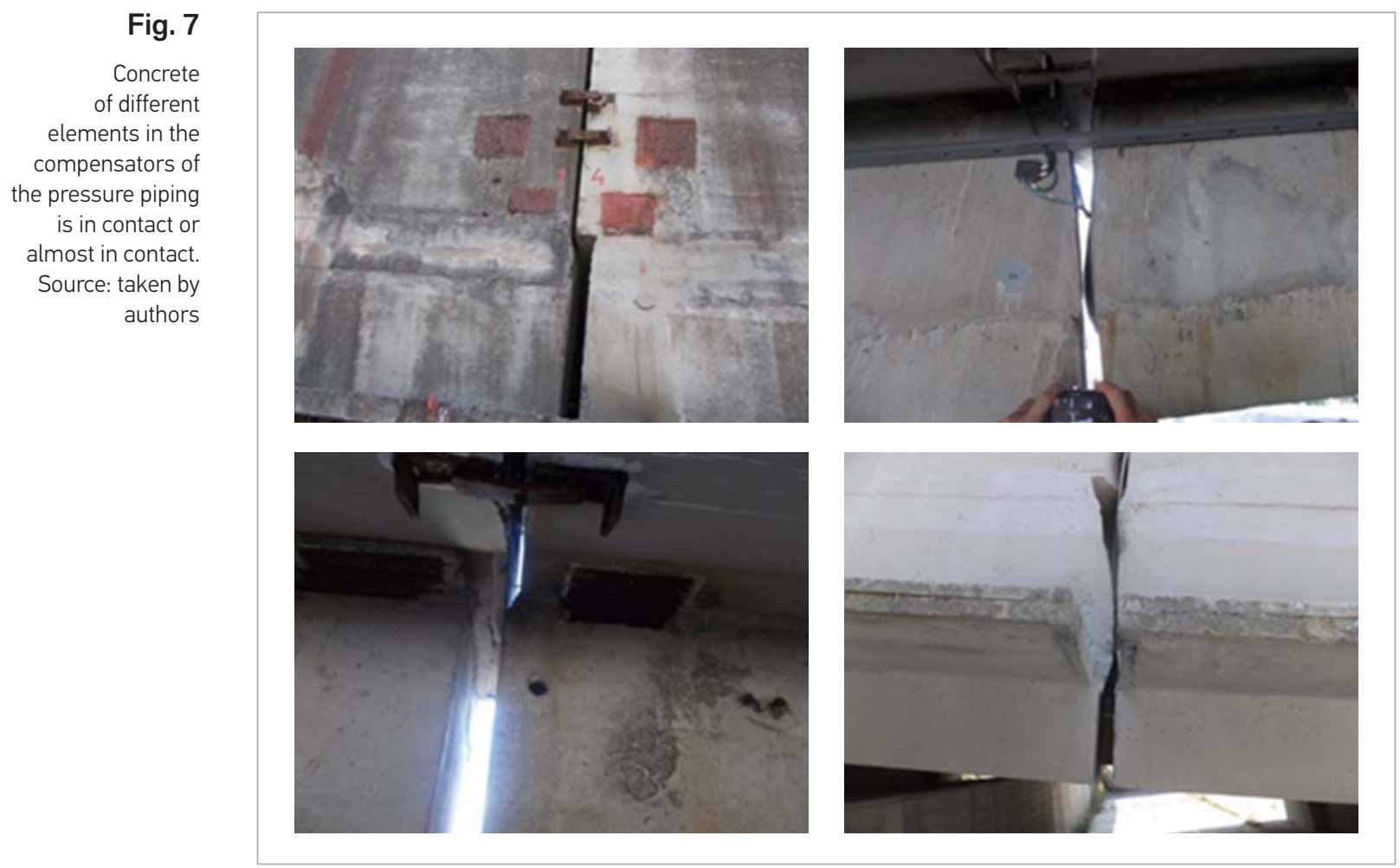




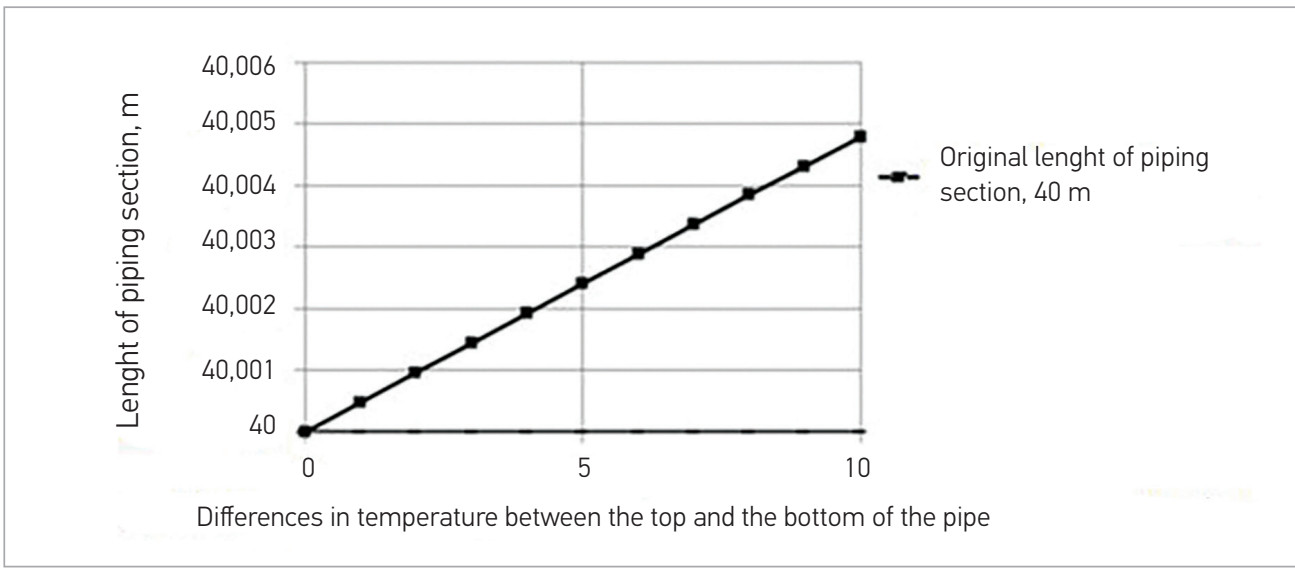

Fig. 8

Temperature deformations along the piping sections when the difference between temperatures is $10^{\circ} \mathrm{C}$. Source: drawn by authors

The surveillance of crack width in the pressure piping of Kruonis PSPP has been performed since 1997. Figure 9 illustrates more detailed measurements and the analysis of change of crack width in level 33 of the first piping from July 30, 2015 to January 05, 2016. Accord- ing to research results presented in Figure 9, the width of cracks in level 33 of the first piping increases in negative temperature. The observation carried out from July 30,2015 , to January 05, 2016, showed that the width of cracks had increased from $0.34 \mathrm{~mm}$ to $0.37 \mathrm{~mm}$.

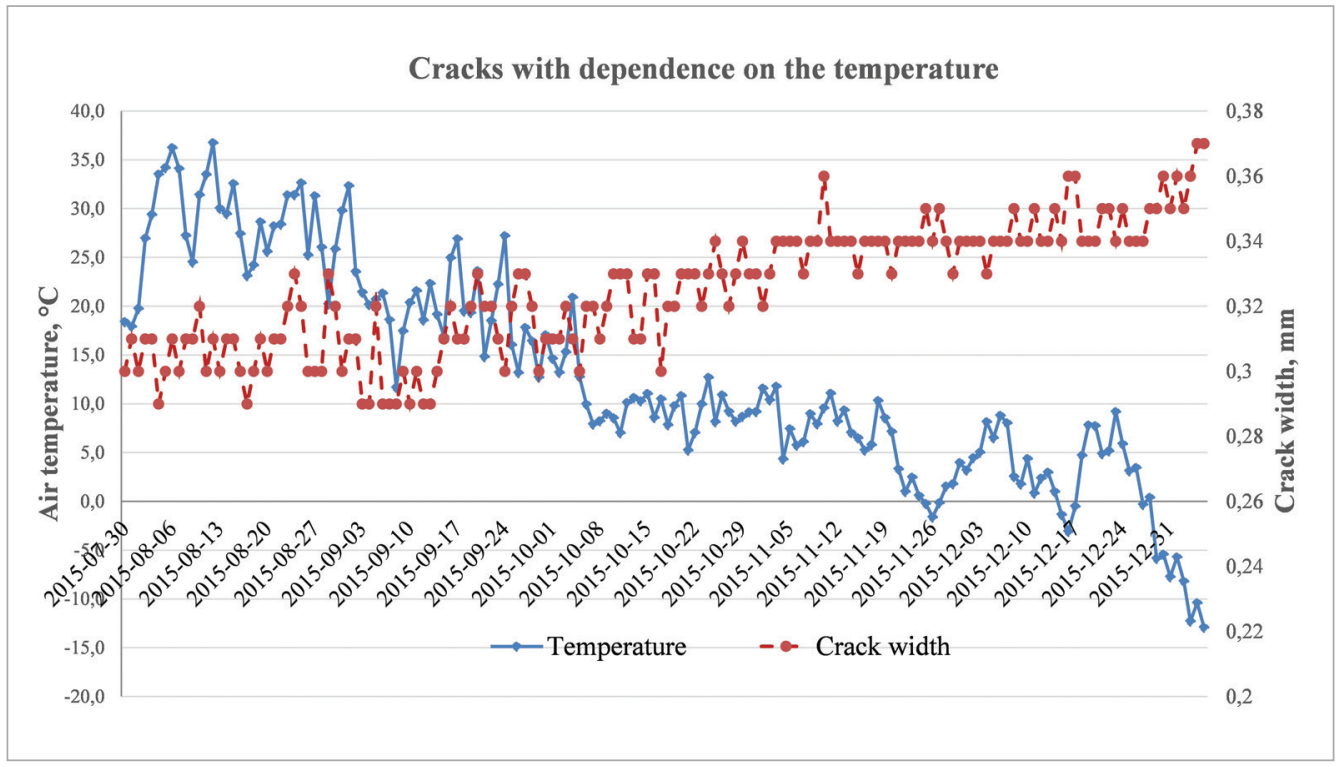

Fig. 9

The change of crack width in level 33 of the first piping during the period of observation from June 30,2015 , to January 5, 2016. Source: drawn by authors

\section{Recommendations for piping reconstruction}

In order to prevent water from passing through the openings on the surface of concrete, it is necessary to perform the following works: to wash the surface of the pipes, to remove the plants, to seal the joints of the pipes and repair other damages of the surface, to prime the surface and to cover it with a bright material which is resistant to temperature deformations (elastic), hydrophobia, $\mathrm{CO}_{2}$ and ultraviolet light, which passes through water vapour so that humidity could disappear from concrete. Part of the third piping was repaired over the period of May to June in 2014 by removing the 
cracked concrete up to reinforcement and replacing it with a new mixture of concrete. After the solidification of concrete, the surface was painted in white colour (Figure 10). Concrete of several neighbouring sections in the piping was also painted.
We consider that the repair by removing cracked concrete would not be reasonable, as it requires a lot of time and financial costs. Besides, it would not stop water from passing into concrete: leaching out of $\mathrm{Ca}(\mathrm{OH})_{2}$ was observed in the repaired and painted area of concrete (Figure 11).
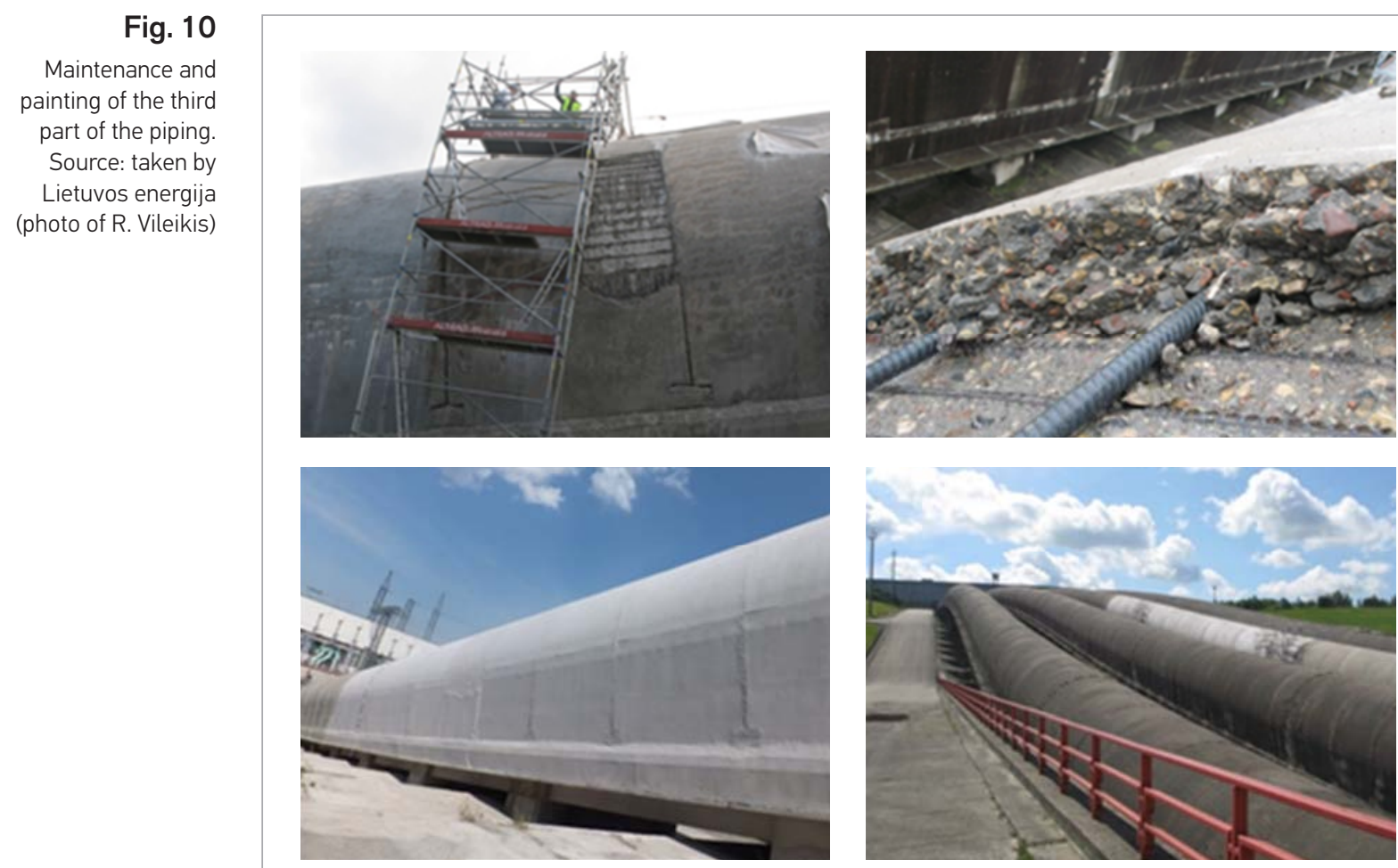

\section{Fig. 11}

Inconsiderable leaching out of $\mathrm{Ca}(\mathrm{OH})_{2}$ in the repaired and painted part of the third piping. Source: taken by authors

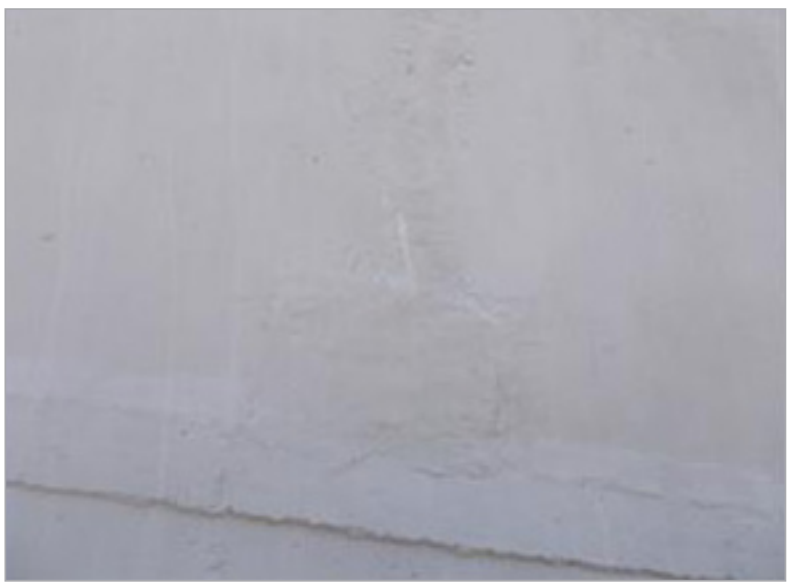

Negative impact of temperature deformations could be reduced by installing piping insulation and covering the surface of the pipes with an elastic, hermetic material, e.g. a sprayed bicomponent system - polyurethane foam covered with acrylics compounds on top with a low level of solar energy absorption.

Figure 12 shows the dropdowns of temperature in the wall of the pressure piping, when the temperature inside the pipe is $+4^{\circ} \mathrm{C}$ and outside the pipe $-20^{\circ} \mathrm{C}$; howev$\mathrm{er}$, the top of the pipe is covered with thermal insulation, the resistance of which is $R_{t}=1 \mathrm{~m}^{2} \mathrm{~K} / \mathrm{W}$.

The following heat conductivity coefficients were used for calculations $\lambda$ :

$$
\begin{aligned}
& \lambda_{\text {concrete }}=2,4 \mathrm{~W} /(\mathrm{m} \cdot \mathrm{K}), \lambda_{\text {steel }}=50 \mathrm{~W} /(\mathrm{m} \cdot \mathrm{K}), \\
& \lambda_{\text {polyurethane foam }}=0,36 \mathrm{~W} /(\mathrm{m} \cdot \mathrm{K}) .
\end{aligned}
$$



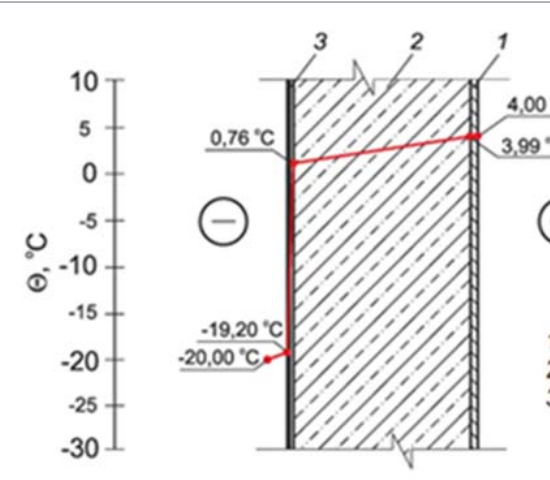

1 - steel plate $10 \mathrm{~mm}$

2 - concrete $390 \mathrm{~mm}$

3- heat insulation $R_{1}=1 \mathrm{~m}^{2} \mathrm{KWW}$

\section{Suggestions for improvement of the technical state of the pressure piping}

It would be necessary:

1 To renovate the joints in compensation for temperature deformations so that their values would correspond to those of the design;

2 To renovate the worn protective cover of the inclusive steel details and other steel elements;

3 To remove the damages (dimples, crumbled areas and leaky joints) from the surface of piping concrete. Concrete repairing materials, which are elastic and cohesive, should be used to repair the joints and other damages. These materials must meet the requirements of standards EN 1504-2 and EN 1504-3.

4 To do periodical washing of the surface of the piping, which is covered with dust and is considerably dark, and to cover it with an elastic, hermetic, hydrophobic and resistant material to $\mathrm{CO}_{2}$ with a low level of solar energy absorption and to insulate the piping, in order to reduce the formation of surface cracks caused by temperature deformations, water passing through existing cracks and the speed of concrete carbonisation.

\section{References}

Bofang Z. (2014). Thermal Stresses and Temperature Control of Mass Concrete. Tsinghua University Press. Elsevier Inc. 487 p.

Chen, J., Masoud, S. and Xuehui, A. (2005). Experimental and numerical study of cracking behaviour of openings in concrete dams. Computers and Structures 83, No 8-9: 525-535.

EN 206:2014. Betonas. Specifikacija, eksploatacinès savy-

\section{Conclusions}

1. The following defects and damages were found in the pressure piping of Kruonis PSPP: in some compensators, concrete in the sections of neighbouring pipes is in contact or almost in contact; the surface of the piping is cracked due to the impact of temperature deformations; precipitation water passing through the cracks leaches out $\mathrm{Ca}(\mathrm{OH})_{2}$ from concrete; steel elements are affected by corrosion.

2 The research shows that the layer of dust results in humidity from the precipitations, which needs more time to evaporate, and in the darker surface, which heats up more because of sun radiation. This is the cause of different temperature deformations and stresses at the top and the bottom of the piping inasmuch as outside and inside the piping.

3 According to research results presented in Figure 9 , the width of cracks in level 33 of the first piping increases in negative temperature. The observation carried out from July 30, 2015, to January 02, 2016, showed that, in negative temperature, the width of cracks had increased from $0.34 \mathrm{~mm}$ to $0.37 \mathrm{~mm}$. bès, gamyba ir atitiktis. Betonas. Bandymo metodai. Betono mišinio stabilumo nustatymas.

EN 1504-2:2004. Betoninių konstrukcijų apsauginiai ir remontiniai produktai bei sistemos. Apibrežtys, reikalavimai, kokybès kontrolè ir atitikties ivertinimas. 2 dalis. Betono paviršiaus apsaugos sistemos. 
EN 1504-3:2006. Betoninių konstrukciju apsaugos ir remonto produktai bei sistemos. Apibrezžtys, reikalavimai, kokybès kontrolè ir atitikties jvertinimas. 3 dalis. Konstrukcinis ir nekonstrukcinis taisymas.

Gelžbetoninių hidrotechninių statinių techninès būklès jivertinimo metodikos sukūrimas, ju naudojimo darbų sudèties ir periodiškumo nustatymas pagal îrenginių būklès klasifikavimą: mokslinio tiriamojo darbo, atlikto pagal autorinę sutarti nr.AT9.3, ataskaita (1997). Vadovas L. Lindišas. Kaunas-Akademija, $83 \mathrm{p}$.

Gelžbetoninių hidrotechninių statinių techninès būklès ivertinimo metodikos sudarymas, gelžbetoninių HTS būklès ivertinimas ir ju susisteminimas: darbo, atlikto pagal autorinę sutarti AT 9.3, 1998 metų tarpinè ataskaita (1998). Vadovas L. Lindišas. Kaunas-Akademija. 102 p.

Gurskis V. (2008). Statybinès medžiagos. Mokomoji knyga. Kaunas: Ardiva, 136p.

Iskander, M. (2013). Relationship between Temperature and Earth Pressure for a Rigidly Framed Earth Retaining Structure. Geotechnical and Geological Engineering, 10.1007/s10706012-9606-2: 519-539. https://doi.org/10.1007/s10706-0129606-2

Jokūbaitis V. (2007). Statinių gelžbetoninių ir mūrinių konstrukciju techninès būklès tyrimai ir vertinimas. Vilnius: Technika. https://doi.org/10.3846/952-S

Jokūbaitis, V. Šiaučiuvėnas, G. (2012). Statinių konstrukcijų techninès būklès vertinimas: mokomoji knyga. Vilnius: Technika. 201 p. https://doi.org/10.3846/1302-S

Kruonio HAE hidrotechnikos statinių techninès saugos vertinimo taisykles (2007). Kruonio HAE. 24 p.

Kruonio HAE statinių priežiūros taisyklès Nr. H-1a. (2008). Kruonis. 41 p.

Kruonio HAE hidrotechnikos statinių techninès būklès kompleksinis vertinimas (2014). Darbo vadovas - V. Damulevičius, vykdytojai: V. Gurskis, R. Skominas, R. Šadzevičius ir kt. Kruonis, Lietuvos energija.

Naik, T., Kraus, R. and Kumar, R. (2011). Influence of Types of Coarse Aggregates on the Coefficient of Thermal Expansion of Concrete. J. Mater. Civ. Eng. 10.1061/(ASCE)MT.19435533.0000198: 467-472. https://doi.org/10.1061/(ASCE) MT.1943-5533.0000198

Ramonas Č. (2007). Kruonio HAE hidrotechnikos statinių techninès saugos vertinimo taisyklès. Autorinio darbo pagal sutarti Nr. 07-0221, sudarytą 2007 m. vasario mèn. 22 d. su
Lietuvos hidroenergetiku asociacija, baigiamoji ataskaita. Kaunas.

ST 120793378.02:2015. Tiltai, viadukai, estakados, seklieji tuneliai, atraminès sienos, lynų keliai. Vilnius. Lietuvos melioracijos imonių asociacija.

ST 120793378.05:2015. Hidrotechninès statybos darbai. Vilnius. Lietuvos melioracijos įmonių asociacija.

STR 2.02.06:2004. Hidrotechnikos statiniai. Pagrindinès nuostatos.

STR 2.05.15:2004. Hidrotechnikos statiniu poveikiai ir apkrovos.

STR 1.03.01:2016 Statybiniai tyrimai. Statinio avarija

STR 2.05.05:2005. Betoninių ir gelžbetoninių konstrukcijų projektavimas.

STR 2.05.18:2005. Betoninès ir gelžbetoninès užtvankos ir ju konstrukcijos.

STR 1.12.03:2006. Hidrotechnikos statinių techninès priežiūros taisyklès.

Siddiqui, M., Fowler, D. (2014). Effect of Internal Water Pressure on the Measured Coefficient of Thermal Expansion of Concrete. Journal of Materials in Civil Engineering, 10.1061/ (ASCE)MT.1943-5533.0001095, 04014151. http://ascelibrary. org/doi/abs/10.1061/(ASCE)MT.1943-5533.0000198. https:// doi.org/10.1061/(ASCE)MT.1943-5533.0001095

Šadzevičius, Raimondas; Patašius, Algimantas; Mikuckis, Feliksas (2009). Hidromazgu vandens raminimo baseino gelžbetoninių rastų plyšių klasifikacija pagal pavojingumą konstrukcijai. Vandens ūkio inžinerija No.35(55):110-116.

Wang, J., Wang, S. and Jin, F. (2013). Measurement and Evaluation of the Thermal Expansion Coefficient of Rock-Filled Concrete. Journal of Testing and Evaluation 10.1520/ JTE20120293, 20120293. https://doi.org/10.1520/JTE20120293

Zhou, C., Shu, X., Huang, B. (2014). Predicting concrete coefficient of thermal expansion with an improved micromechanical model. Construction and Building Materials 10.1016/j. conbuildmat.2014.06.039: 10-16. https://doi.org/10.1016/j. conbuildmat.2014.06.039

Zhou, C., Huang, B., Shu, X. (2012). Micromechanical Model for Predicting Coefficient of Thermal Expansion of Concrete. Journal of Materials in Civil Engineering 10.1061/(ASCE)MT.19435533.0000663: 1171-1180. https://doi.org/10.1061/(ASCE) MT.1943-5533.0000663 


\section{Temperatūros kaitos įtaka plyšių atsivèrimui Kruonio HAE sléginio vamzdyno gelžbetoniniame apvalkale}

\section{Raimondas Šadzevičius, Vincas Gurskis, Rytis Skominas,} Tatjana Sankauskienè

Hidrotechninės statybos inžinerijos institutas, Vandens ūkio ir žemètvarkos fakultetas, Aleksandro Stulginskio universitetas, Kaunas, Lietuva

Plyšiai klasifikuojami pagal ju geometrinius (ilgi, ploti, gyli) ir statistinius parametrus (vidutinis plyšiu skaičius ir dispersija ploto vienete), pagal pavojingumą konstrukcijai ir kt. Šiame darbe analizuoti dèl temperatūros kaitos atsiverę plyšiai Kruonio hidroakumuliacinès elektrinès slèginio vamzdyno gelžbetoniniame apvalkale. Ivertinus vamzdynu techninę būklę, detaliau analizuoti plyšiai ir deformacijos dèl temperatūros perkričių. Pateikiamos būdingos iliustracijos, skaičiavimai bei rekomendaciniai pasiūlymai šių pažaidų remontui.

Raktiniai žodžiai: temperatūros kaita, hidrotechnikos statiniai, gelžbetoniniai vamzdynai, plyšiai. 